Article

\title{
Projected Near-Surface Wind Speed Trends in Lithuania
}

\author{
Justė Jankevičienė * and Arvydas Kanapickas
}

Lithuanian Energy Institute, 44403 Kaunas, Lithuania; arvydas.kanapickas@lei.lt

* Correspondence: juste.jankeviciene@lei.lt

check for

updates

Citation: Jankevičienè, J.;

Kanapickas, A. Projected NearSurface Wind Speed Trends in Lithuania. Energies 2021, 14, 5425. https://doi.org/10.3390/en14175425

Academic Editors: Antonio Rosato and Eugen Rusu

Received: 4 July 2021

Accepted: 26 August 2021

Published: 31 August 2021

Publisher's Note: MDPI stays neutral with regard to jurisdictional claims in published maps and institutional affiliations.

Copyright: (c) 2021 by the authors. Licensee MDPI, Basel, Switzerland. This article is an open access article distributed under the terms and conditions of the Creative Commons Attribution (CC BY) license (https:// creativecommons.org/licenses/by/ $4.0 /)$.

\begin{abstract}
Developing wind energy in Lithuania is one of the most important ways to achieve green energy goals. Observational data show that the decline in wind speeds in the region may pose challenges for wind energy development. This study analyzed the long-term variation of the observed 2006-2020 and projected 2006-2100 near-surface wind speed at the height of $10 \mathrm{~m}$ over Lithuanian territory using data of three models included in the Coupled Model Intercomparison Project phase 5 (CMIP5). A slight decrease in wind speeds was found in the whole territory of Lithuania for the projected wind speed data of three global circulation models for the scenarios RCP2.6, RCP4.5, and RCP8.5. It was found that the most favorable scenario for wind energy production is RCP2.6, and the most unfavorable is the RCP4.5 scenario under which the decrease in wind speed may reach $12 \%$. At the Baltic Sea coastal region, the decline was smaller than in the country's inner regions by the end of the century. The highest reduction in speed is characteristic of the most severe RCP8.5 scenario. Although the analysis of wind speeds projected by global circulation models (GCM) confirms the downward trends in wind speeds found in the observational data, the projected changes in wind speeds are too small to significantly impact the development of wind farms in Lithuania.
\end{abstract}

Keywords: wind speed; RCP scenarios; climate change; IPCC projections

\section{Introduction}

Climate change is one of the major concerns nowadays. Every country tries to reduce emissions and take other actions to prevent the strong impact of global warming. Therefore, the European Union (EU) has released the directive 2018/2001, setting aims and goals to fight against increasing climate change [1]. One of the goals is to reduce $\mathrm{CO}_{2}$ emissions by $40 \%$. The emission cut is proposed to implement by boosting energy production from renewable energy, which includes wind, solar, hydro, etc. Besides the directive of the EU, every country sets its own goals for climate change mitigation. For example, the goal set by the Lithuanian government is to reach at least $21 \%$ of the total electricity produced by renewable energy sources (RES) by 2030 [2-5].

Wind energy has significant potential to meet the challenges of decarbonization. According to the International Renewable Energy Agency (IRENA), wind electricity production reached 1412 TWh in 2019 [6]. Wind energy is one of the most popular RES in Lithuania and has the most significant expansion. Annual energy produced in wind parks in 2015 was $810 \mathrm{GWh}$, and in 2019 it reached up to $1500 \mathrm{GWh}$ [7].

Wind energy projects are usually planned for decades to come, so possible variations in wind speed can significantly impact the amount of energy generated. The significant impacts of climate change on wind resources are as follows: (1) the reduction of wind power generation because of very high (extreme) or very low winds [8], (2) the output of wind turbines being greatly affected because of energy dependence on the cube of wind speed, and (3) changes in the daily or seasonal distribution of wind [9]. Recent research suggests that wind speeds will change in various regions of the world over the course of this century [10-12].

The development of a wind farm usually starts with an accurate analysis of wind performance in a specific area. In general, the wind estimation for new wind farms 
is accomplished using measurement data of the past years and applying them for the subsequent reanalysis over the next 20 years. However, some investigations have shown that in Lithuania, wind speeds are decreasing if the time spans required to implement wind farm projects are considered. For example, in the paper [13] it was found that, for analyzed Lithuanian sites, the reductions of mean speed in 1977-2010 were $-0.95 \mathrm{~m} / \mathrm{s}$ (Klaipeda hydrometeorological station (HMS), coastal region), $-0.70 \mathrm{~m} / \mathrm{s}$ (Kaunas HMS, central region), and $-0.25 \mathrm{~m} / \mathrm{s}$ (Laukuva HMS, central region). Because of cubic dependence, the changes in the amount of produced energy were more considerable: $-39 \%$ in the Klaipeda site, $-38 \%$ in the Kaunas site, and $-24 \%$ in Laukuva. The same results were confirmed by the report published by the Lithuanian Hydrometeorological Service [14]. Therefore, the future viability of wind plant installations in Lithuania is very sensitive to wind speed changes induced by climate warming, which have to be evaluated.

The projected wind speed data are usually used from simulations based on Representative Concentration Pathways scenarios (IPCC AR5 WG 2013) [15]. RCP2.6 and RCP8.5 represent the most contrasting climate change scenarios. The first one considers the most severe climate change conditions, and the second one considers the mildest ones. Therefore, the simulated data cover the whole range of wind speed changes because of climate change. A comprehensive review of projected changes in wind speed in the 21st century using representative concentration pathways (RCP) global climate change scenarios is provided here [16].

Recent studies related to the projected changes in wind speed at global and local scales are ambiguous $[8,9,17,18]$. On the one hand, the analysis shows some wind speed increase in Northern and Central Europe and a decrease in Southern Europe [17]. On the other hand, the analysis of RCP data in other papers reveals that wind energy density reduction will be the general trend [18]. The research conducted in several studies shows that, according to the RCP projections, the wind speeds will increase over the 21st century in the regions surrounding the Baltic Sea $[10,13,17]$. However, the coarse resolution of global climate models limits the possibilities of wind resource assessment on the regional or local scale.

The objectives of this study are the following: to examine long-term changes in the observed wind speed data over the last 14 years (2006-2020); to analyze the annual mean wind speed trends for the 21st century under the mildest (RCP2.6), realistic (RCP4.5), and the most severe (RCP8.5) climate change scenarios for the Lithuania territory; and to assess if the observed decline in wind speed will be crucial for the development of wind energy projects in the near and far future in Lithuania.

\section{Methodology}

\subsection{Climate Data}

Observed wind speed data were taken from the National Oceanic and Atmospheric Administration (NOAA). NOAA provides a global surface summary of the day data (GSOD), which includes temperature, precipitation, wind speed and gust, atmospheric pressure, etc. [19]. Recordings of meteorological observations have coverage from 1901 until 2020, even though many data points are missing for early years. In this study, historical data from 2006 until 2020 were used as the reference period (RF). That gives the possibility to find a relation between observed and projected data, which is necessary to compare these data.

Projected wind speed data are based on the RCP scenarios developed by the International Panel on Climate Change (IPCC) due to continuous efforts in assessing the causes and the consequences of the ongoing climate change [15]. The latest RCP scenarios are distinguished by the total radiative forcing at the end of this century, measured in $\mathrm{W} / \mathrm{m}^{2}$, and therefore are named as follows: RCP2.6, RCP4.5, RCP6.0, and RCP8.5. The RCP2.6 scenario is the mildest one; the concentration of greenhouse gases will achieve $490 \mathrm{ppm}$ in $\mathrm{CO}_{2}$ equivalents by 2100 . The most severe RCP8.5 scenario represents the highest increase in $\mathrm{CO}_{2}$ concentration - up to $1370 \mathrm{ppm}$ by 2100 . The dependence of global temperature on the concentration of greenhouses in the atmosphere is evident, but future trends may 
have different patterns. For this study, the wind data from three global circulation models were used, namely, the Max Planck Institute for Meteorology Earth System (MPI-ESM-LR) model, the Hadley Centre Global Environmental Model (HadGEM2-ES), and the Institute Pierre Simon Laplace (IPSL-CM5A-MR) model. Three RCP scenarios were taken into consideration: the most contrasting scenarios, RCP2.6 and RCP8.5, and the intermediate scenario RCP4.5, which is believed may result in an increase of global temperatures below $2{ }^{\circ} \mathrm{C}$, i.e., below the value close to the Paris agreement [15]. The daily mean near-surface wind speed for all selected models and scenarios for the period 2006-2100 was obtained from the portal of the Earth System Grid [20].

\subsection{Wind Speed Analysis Methods}

Projected wind data were retrieved from the IPCC Data Distribution Center [20]. Future projections for the wind speed were extracted from the downloaded files, taking the data for the nearest point to the meteorological station's site (Table 1 and Figure 1). For example, the low-resolution configuration of the HAD model (HadGEM2-ES) uses an average horizontal grid resolution of 1.875 (longitude) $\times 1.865$ (latitude) in degrees. The nearest point to Kaunas, where the meteorological station is located, has coordinates $54^{\circ} 22^{\prime}$ $\mathrm{N}, 23^{\circ} 25^{\prime} \mathrm{E}$. When extracting projected wind speed data from the downloaded files, the closest grid point to the given coordinates was found, and then the data were extracted for this point [21]. The same procedure was applied to all 23 hydrometeorological stations in Lithuania (Table 1).

Table 1. Meteorological stations in Lithuania.

\begin{tabular}{|c|c|c|c|c|}
\hline Station & Latitude, ${ }^{\circ} \mathbf{N}$ & Longitude, ${ }^{\circ} \mathbf{E}$ & Altitude, m & Region \\
\hline Biržai & 55.20 & 24.76 & 63 & Northern \\
\hline Dotnuva & 55.37 & 23.89 & 48 & Central \\
\hline Dūkštas & 55.52 & 26.32 & 151 & Central \\
\hline Kaunas & 54.90 & 23.89 & 48 & Central \\
\hline Kybartai & 54.64 & 22.76 & 70 & Southern \\
\hline Klaipèda & 55.71 & 21.13 & 21 & Coastal \\
\hline Laukuva & 55.62 & 22.23 & 166 & Coastal \\
\hline Lazdijai & 54.23 & 23.52 & 126 & Southern \\
\hline Mažeikiai & 56.31 & 22.34 & 81 & Coastal \\
\hline Nida & 55.30 & 21.00 & 4 & Coastal \\
\hline Panevèžys & 55.73 & 24.36 & 61 & Northern \\
\hline Raseiniai & 55.38 & 23.12 & 125 & Central \\
\hline Rokiškis & 55.96 & 25.59 & 133 & Northern \\
\hline Šiauliai & 55.92 & 23.32 & 107 & Northern \\
\hline Šilutė & 55.34 & 21.47 & 11 & Coastal \\
\hline Švenčionys & 55.13 & 26.16 & 230 & Central \\
\hline Tauragè & 55.25 & 22.29 & 36 & Coastal \\
\hline Telšiai & 55.99 & 22.20 & 128 & Coastal \\
\hline Ukmergė & 55.25 & 24.76 & 64 & Central \\
\hline Utena & 55.50 & 25.60 & 113 & Central \\
\hline Varèna & 54.20 & 24.58 & 136 & Southern \\
\hline Vèžaičiai & 55.72 & 21.48 & 56 & Coastal \\
\hline Vilnius & 54.68 & 25.29 & 148 & Southern \\
\hline
\end{tabular}




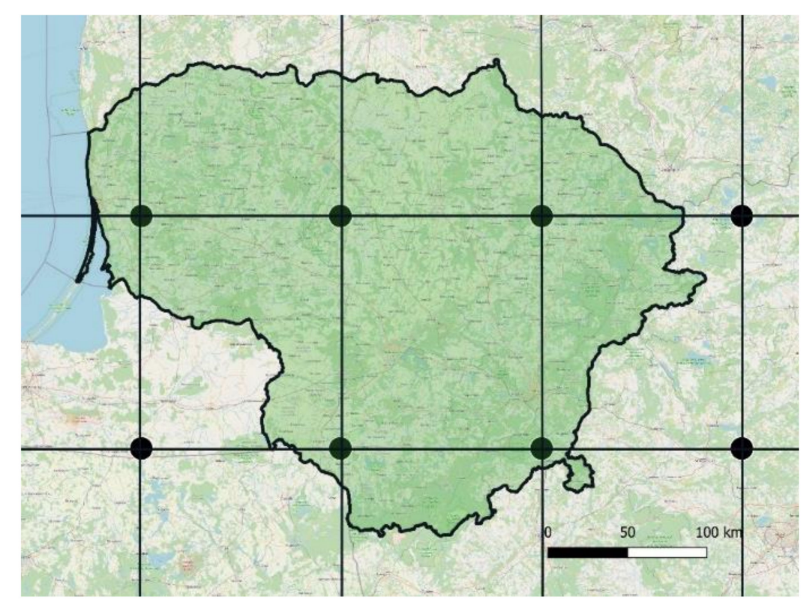

Figure 1. Grid points of the global climate model HadGEM2-ES over Lithuania. Black points represent points whose data are available for the research. After data extraction, the verification of the projected wind speed data was performed. The Pearson correlation coefficient (PCC) was calculated to check the correlation of these two datasets.

Wind speed analysis was carried out at near-surface points or $10 \mathrm{~m}$ height. This altitude is suitable for assessing the change in wind speed for the whole country, without considering the different surface terrains. It should also be noted that a country's nearsurface wind speed analysis can easily be applied to an actual wind turbine site anywhere in the country.

Downscaling was performed using generalized linear models (GLMs). GLMs are an extended version of the traditional linear regression. Wind speed data were downscaled using Formula (1) [22]:

$$
E(Y)=g^{-1}(X \beta)
$$

where $X$ is the predictor, $E(Y)$ is the expected predictor and value, $g$ is the link function, and $\beta$ is the parameter, estimated by a least-square iterative algorithm.

The assessment of the change in wind speed was carried out using percentage values. The percentage change of wind speed from the projected wind speed data reference period (2006-2020) was calculated for every year, until 2100. This can be expressed by Equation (2):

$$
a_{i}=\frac{\left(R F_{p}-w s_{i}\right) \cdot 100}{R F_{p}}
$$

where $a_{i}$ is the projected annual wind speed change ( $i$ represents year) in $\%, R F_{p}$ is the mean wind speed over the reference period using projected data in $\mathrm{m} / \mathrm{s}$, and $w s_{i}$ is the projected annual mean wind speed (i represents year) in $\mathrm{m} / \mathrm{s}$.

Then expected annual wind speed for the 21st century is recalculated using the observed mean wind speed over the reference period and the projected wind speed change:

$$
w_{i}=\frac{\left(100-a_{i}\right) \cdot R F_{O}}{100}
$$

where $w_{i}$ is the expected annual wind speed ( $i$ represents year) in $\mathrm{m} / \mathrm{s}$, and $R F_{O}$ is the mean wind speed over the reference period. In this study, bias correction was not applied for the projected wind speed data; therefore, the projected data for the 2006-2020 period were chosen as the reference period.

The mean absolute percentage error (MAPE) was also calculated to validate the data using the following formula [23]:

$$
M A P E=\frac{100}{n} \sum_{i=1}^{n} \frac{\left|x_{i}-y_{i}\right|}{x}
$$


where $x$ is the projected data points $(i=1, \ldots, n)$, and $y$ is the observed data points $(i=1$, $\ldots, n)$.

\subsection{Software}

Data extraction, analysis, calculation, and plot drawing were implemented using the Rstudio (Boston, Massachusetts, USA) and R software packages. The downloaded projected data were extracted and downscaled at selected locations using the cmsaf, ncdf4, and downscaleR packages, which are designed to process the standard type of meteorological data files $[22,24,25]$. This step is performed using the coordinates of the desired geographical location. Using these coordinates, the nearest point is found and the data for this point are extracted and downscaled. Further processing of the data is programmed using the dplyr, base, and reshape packages, which are standard $R$ packages. These packages allow for easy and efficient data manipulation and formatting. Even though $\mathrm{R}$ is possible to use for map composing, a free and open-source Geographic Information System QGIS (Gruet, Switzerland) was preferred because this application does not require coding and saves time compared to maps production using R [26]. One of the main functions used in QGIS was inverse distance weighted (IDW) interpolation. This function weights the sample points in such a way that as the distance to the point to be created increases, the weight of the other point decreases. The detailed description of calculations implemented in the IDW interpolation can found here [27].

\section{Results}

Projected wind speed data were downscaled with the appropriate $\mathrm{R}$ packages [28], which find the closest point to the station. Then the change of projected wind speed was analyzed using three scenarios, RCP2.6, RCP4.5, and RCP8.5, according to three global climate models, MPI-ESM-LR, IPSL-CM5A-MR, and HadGEM2-ES. In order to analyze the geographical patterns of wind speed, the projected data for all hydrometeorological (HM) stations were used to create the wind map of Lithuania, averaging all three models (IPSL, MPI, and HAD) into one. Then, data validation was performed. The PCC and $p$-value are presented in Table 2. The PCC shows that there is a strong positive correlation between the observed and projected wind speed data (0.5 to 0.8 ), which range from 0.505 to 0.794 . The data are statistically significant at 20 out of 23 hydrometeorological stations, where $p<0.05$. Additionally, the mean absolute percentage error (MAPE) was calculated. The highest value of MAPE was $0.47 \%$ at the Taurage HM station, which indicates high accuracy of the projected wind speed data. Therefore, further processing of the data is considered statistically reliable and significant.

Table 2. Results of data validation.

\begin{tabular}{ccccccc}
\hline Station & Region & PCC & $p$ Value & MK & $p$ Value & MAPE, $\%$ \\
\hline Biržai & Northern & 0.598 & 0.024 & 0.429 & 0.036 & 0.29 \\
\hline Dotnuva & Central & 0.682 & 0.007 & 0.451 & 0.026 & 0.25 \\
\hline Dūkštas & Central & 0.792 & $<0.001$ & 0.626 & 0.001 & 0.24 \\
\hline Kaunas & Central & 0.626 & 0.017 & 0.473 & 0.019 & 0.04 \\
\hline Kybartai & Southern & 0.626 & 0.017 & 0.407 & 0.047 & 0.10 \\
\hline Klaipėda & Coastal & 0.550 & 0.042 & 0.451 & 0.026 & 0.30 \\
\hline Laukuva & Coastal & 0.610 & 0.021 & 0.472 & 0.019 & 0.07 \\
\hline Lazdijai & Southern & 0.608 & 0.021 & 0.451 & 0.026 & 0.35 \\
\hline Mažeikiai & Coastal & 0.522 & 0.055 & 0.385 & 0.062 & 0.42 \\
\hline Nida & Coastal & 0.505 & 0.065 & 0.429 & 0.036 & 0.22 \\
\hline Panevėžys & Northern & 0.751 & 0.002 & 0.582 & 0.003 & 0.14 \\
\hline
\end{tabular}


Table 2. Cont.

\begin{tabular}{ccccccc}
\hline Station & Region & PCC & $p$ Value & MK & $p$ Value & MAPE, $\%$ \\
\hline Raseiniai & Central & 0.640 & 0.013 & 0.473 & 0.019 & 0.04 \\
\hline Rokiškis & Northern & 0.790 & $<0.001$ & 0.582 & 0.003 & 0.43 \\
\hline Šiauliai & Northern & 0.699 & 0.005 & 0.582 & 0.003 & 0.34 \\
\hline Šilute & Coastal & 0.541 & 0.046 & 0.451 & 0.026 & 0.04 \\
\hline Švenčionys & Central & 0.794 & $<0.001$ & 0.626 & 0.001 & 0.44 \\
\hline Taurage & Coastal & 0.584 & 0.028 & 0.495 & 0.014 & 0.47 \\
\hline Telšiai & Coastal & 0.526 & 0.053 & 0.363 & 0.079 & 0.27 \\
\hline Ukmerge & Central & 0.735 & 0.003 & 0.560 & 0.004 & 0.18 \\
\hline Utena & Central & 0.787 & $<0.001$ & 0.560 & 0.005 & 0.38 \\
\hline Varèna & Southern & 0.683 & 0.007 & 0.429 & 0.036 & 0.42 \\
\hline Véžaičiai & Coastal & 0.552 & 0.041 & 0.451 & 0.026 & 0.23 \\
\hline Vilnius & Southern & 0.703 & 0.005 & 0.407 & 0.047 & 0.19 \\
\hline PCC-Pearson correlation coefficient. MAPE-mean absolute percentage error. MK-Mann Kendall.
\end{tabular}

The analysis of the wind speed change data was based on three scenarios and the results are shown on the maps in Figure 2. The spatial analysis of wind speed change over the 21st century showed that, under the RCP2.6 scenario, wind speed will remain the same over the entire reference period. The only increase may be expected in the far future in the central part of the country, where a wind speed increase of up to $3 \%(p<0.01)$ is expected (Figure 2, Table 2). Even though the RCP8.5 scenario usually is the most severe, in Lithuania's case, the projected wind speed exhibits neither a substantial decrease nor an increase. As is seen in Figure 2, an insignificant wind speed increase (up to 1.5\%) $(p<0.4)$ in the near future is expected. In the middle future, no decrease in wind speed is foreseen in the coastal region, and a slight wind speed decrease is projected in other parts of the country. By the end of the century, there should be a higher decrease in wind speed, reaching up to $4 \%(p<0.05)$ according to the RCP8.5 scenario. The RCP2.6 and RCP8.5 scenarios show no significant change compared to RCP4.5. Even though the RCP4.5 scenario usually is called the most realistic one [9] and is milder than the RCP8.5 one, it was found that this scenario might have the most significant impact on wind speed change in Lithuania. It is expected that the decrease in wind speed in the central part under the RCP4.5 scenario could reach up to $6 \%(p<0.01)$ in the near and middle future, and even up to $8 \%$ in the far future.

In Table 3, the percentage change in wind speed is given for 23 meteorological stations in Lithuania. The table is divided into scenarios and periods- the near, middle, and far future. The table provides more accurate values, which are complementary to the maps given in Figure 2.

Averaged scenarios showed no significant change in wind speed, except for the RCP4.5 scenario. Therefore, Lithuania's territory was subdivided into four regions: southern, coastal, northern, and central (Figure 3), in order to analyze each model and scenario separately. The stations that are included in each region are listed in in Table 1. Each region was analyzed by all three models and scenarios individually (Figures 4-6). 


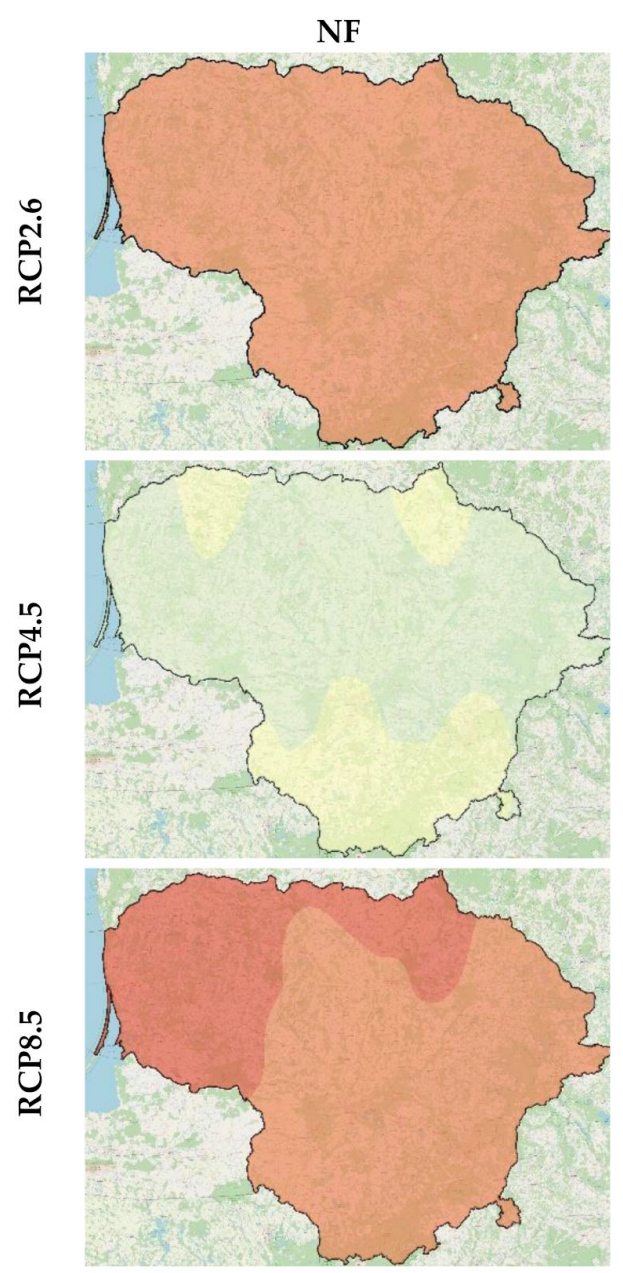

NF - near future (2020-2040) MF - middle future (2040-2060) FF - far future (2080-2100)
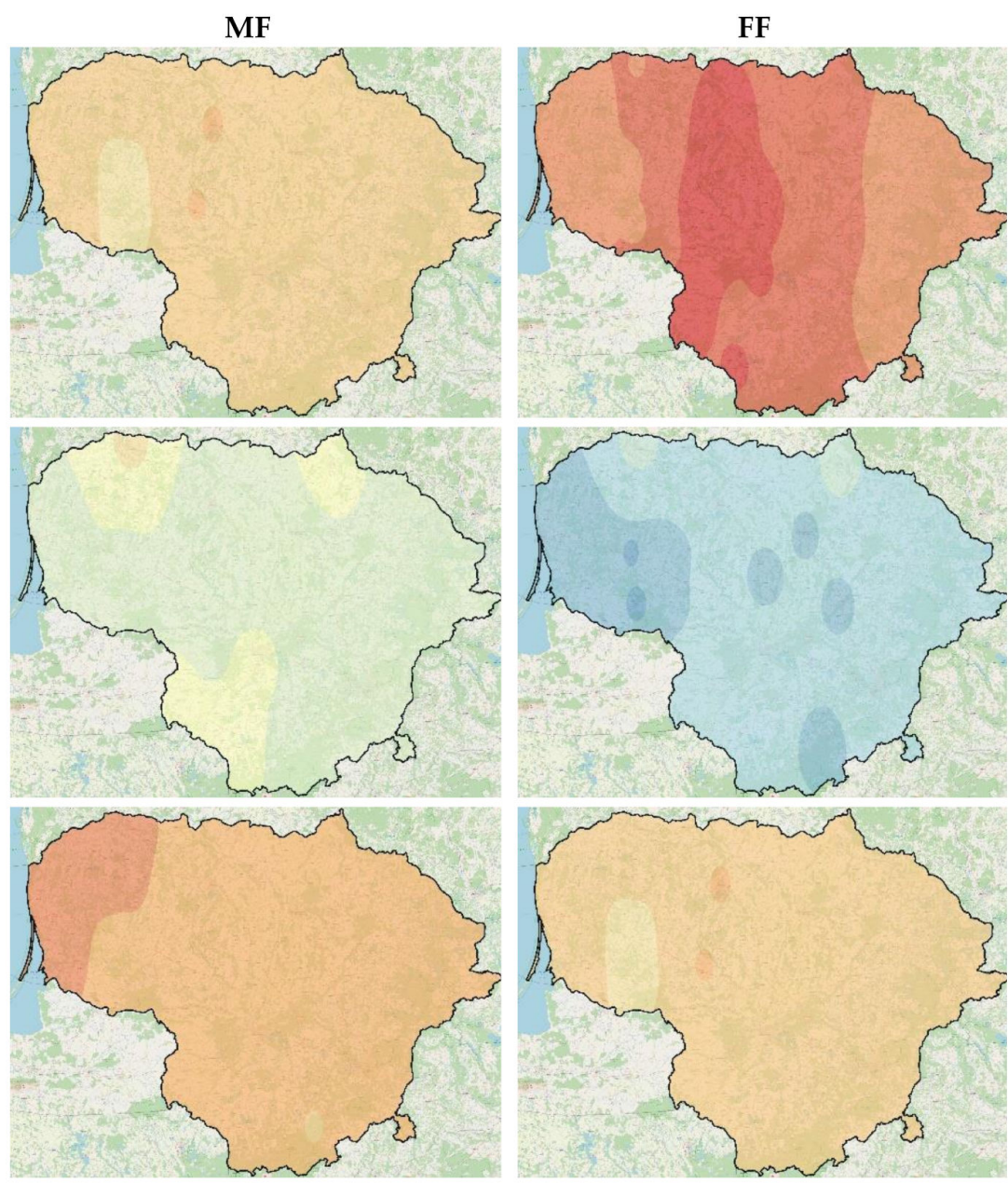

$<=-8 \%$

$-8--7 \%$

$-7--6 \%$

$-6--5 \%$

$-5--4 \%$

$-4--3 \%$
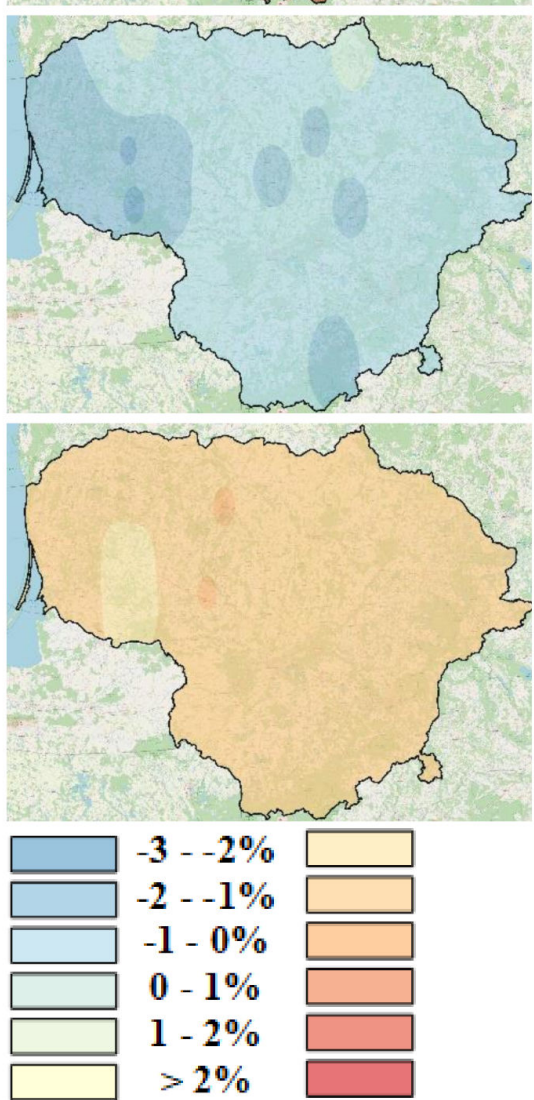

$-3--2 \%$

$-2--1 \%$ $-1-0 \%$ $0-1 \%$ $1-2 \%$

$>2 \%$

Figure 2. Wind speed changes (in \%) in Lithuania over different time periods and scenarios.

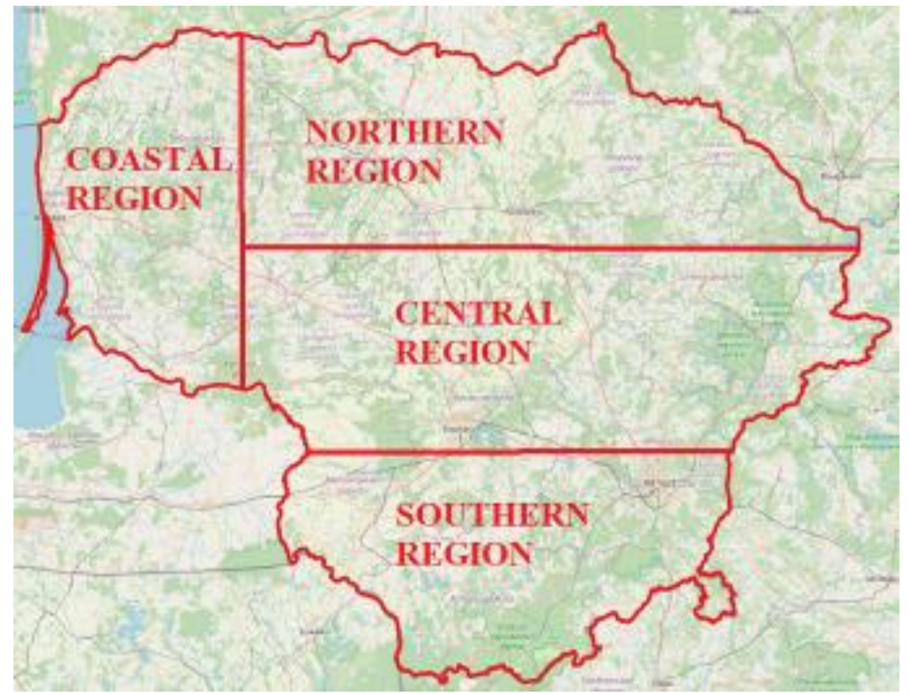

Figure 3. Regional subdivision of the country for the analysis of wind speed changes. 
Table 3. Percentage change in wind speed for 23 meteorological stations over averaged models.

\begin{tabular}{|c|c|c|c|c|c|c|c|c|c|}
\hline \multirow{2}{*}{$\begin{array}{c}\text { Location/Scenario } \\
\text { Change, } \%\end{array}$} & \multicolumn{3}{|c|}{ RCP2.6 } & \multicolumn{3}{|c|}{ RCP4.5 } & \multicolumn{3}{|c|}{ RCP8.5 } \\
\hline & NF & MF & FF & NF & MF & FF & NF & MF & FF \\
\hline Biržai & 0.4 & 0.3 & 1.9 & -3.3 & -3.3 & -5.3 & 0.3 & -0.6 & -1.4 \\
\hline Dotnuva & 0.5 & 1.3 & 2.5 & -4.8 & -4.8 & -7.1 & 1.3 & -0.5 & -1.3 \\
\hline Dūkštas & 0.2 & 0.3 & 0.3 & -4.5 & -4.5 & -6.5 & 0.3 & -0.7 & -1.6 \\
\hline Kaunas & 0.0 & 1.1 & 2.1 & -3.6 & -3.6 & -6.5 & 1.1 & -0.6 & -1.7 \\
\hline Kybartai & 0.2 & 1.3 & 2.6 & -3.8 & -3.6 & -6.3 & 1.3 & -0.6 & -1.3 \\
\hline Klaipèda & 0.1 & 1.0 & 0.3 & -4.6 & -4.3 & -7.5 & 1.0 & 0.1 & -1.7 \\
\hline Laukuva & 0.2 & 1.4 & 0.9 & -4.7 & -4.3 & -8.2 & 1.4 & 0.0 & -2.5 \\
\hline Lazdijai & 0.0 & 1.1 & 2.1 & -3.6 & -3.6 & -6.5 & 1.1 & -0.6 & -1.7 \\
\hline Mažeikiai & 0.5 & 1.2 & 1.0 & -3.3 & -2.4 & -5.2 & 1.2 & 0.3 & -1.7 \\
\hline Nida & 0.1 & 1.0 & 0.3 & -4.6 & -4.3 & -7.5 & 1.0 & 0.1 & -1.7 \\
\hline Panevėžys & 0.4 & 0.9 & 1.2 & -4.3 & -4.4 & -7.1 & 0.8 & -0.9 & -1.9 \\
\hline Raseiniai & 0.7 & 1.5 & 3.0 & -4.9 & -4.8 & -7.0 & 1.5 & -0.5 & -0.9 \\
\hline Rokiškis & 0.3 & 0.4 & 0.1 & -4.2 & -4.3 & -6.7 & 0.4 & -0.8 & -2.0 \\
\hline Šiauliai & 0.7 & 1.5 & 3.0 & -4.9 & -4.8 & -7.0 & 1.5 & -0.5 & -0.9 \\
\hline Šilutè & 0.1 & 1.0 & 0.3 & -4.6 & -4.3 & -7.5 & 1.0 & 0.1 & -1.7 \\
\hline Švenčionys & 0.3 & 0.4 & 0.1 & -4.2 & -4.3 & -6.7 & 0.4 & -0.8 & -2.0 \\
\hline Tauragè & 0.2 & 1.5 & 0.9 & -4.7 & -4.4 & -8.2 & 1.4 & 0.0 & -2.5 \\
\hline Telšiai & 0.1 & 1.1 & 1.0 & -3.7 & -3.3 & -6.4 & 1.1 & 0.2 & -1.9 \\
\hline Ukmergè & 0.4 & 0.9 & 1.2 & -4.3 & -4.4 & -7.1 & 0.8 & -0.9 & -1.9 \\
\hline Utena & 0.3 & 0.4 & 0.1 & -4.2 & -4.3 & -6.7 & 0.4 & -0.8 & -2.0 \\
\hline Varèna & 0.2 & 1.1 & 1.5 & -3.8 & -4.4 & -7.2 & 1.1 & -1.0 & -1.9 \\
\hline Vèžaičiai & 0.1 & 1.0 & 0.3 & -4.5 & -4.3 & -7.5 & 1.0 & 0.1 & -1.7 \\
\hline Vilnius & 0.0 & 0.6 & 0.5 & -3.7 & -4.2 & -6.7 & 0.6 & -0.9 & -2.0 \\
\hline
\end{tabular}

NF-near future (2020-2040); MF-middle future (2040-2060); FF-far future (2080-2100).

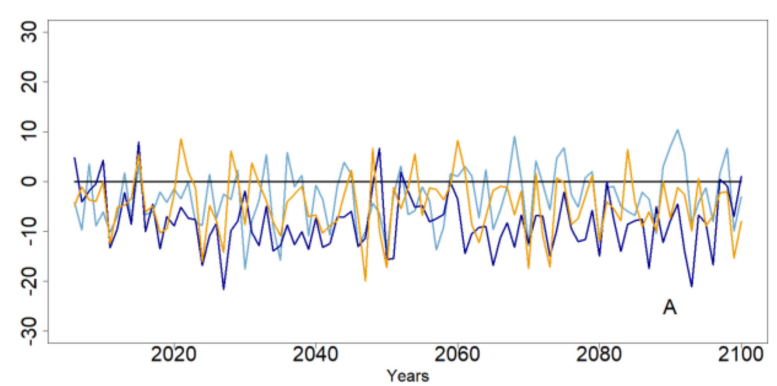

(a)

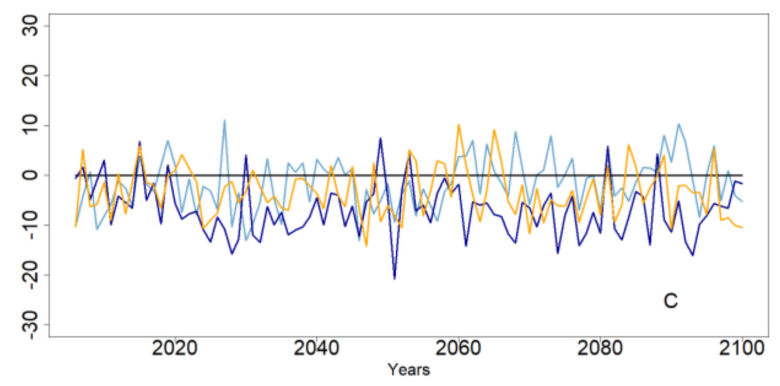

(c)

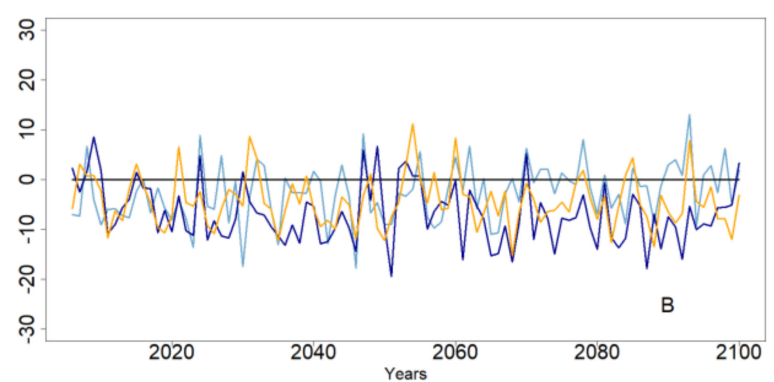

(b)

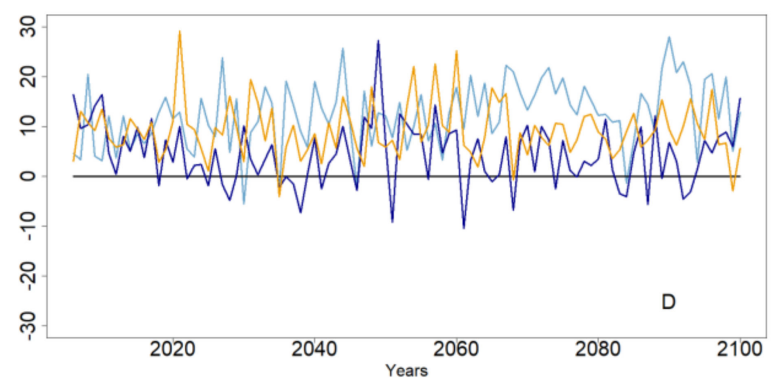

(d)

\section{$\mathrm{RCP} 2.6-\mathrm{RCP} 4.5-\mathrm{RCP} 8.5-\mathrm{RF}$}

Figure 4. Projected percentage change in wind speed compared to the observed reference period 2006-2020 in different regions of Lithuania based on the IPSL-CM5A-MR model: (a)—northern, (b)—southern, (c)—central, and (d)—coastal. 


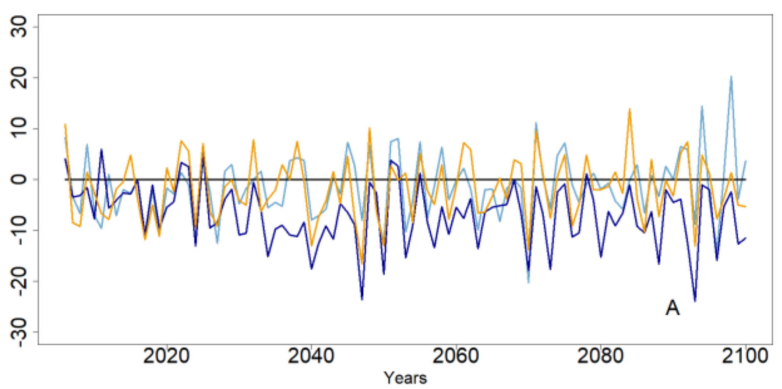

(A)

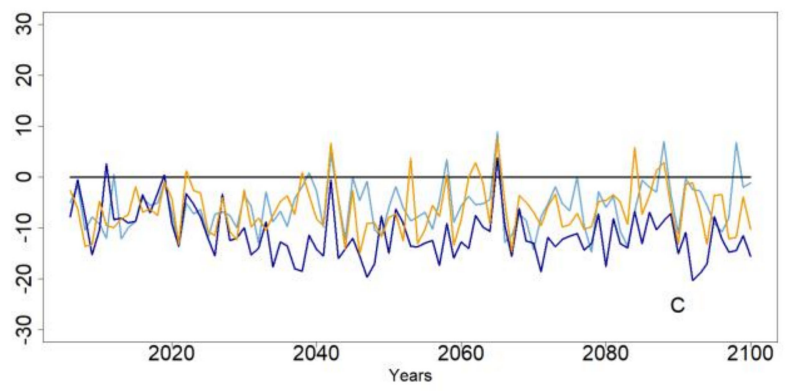

(C)

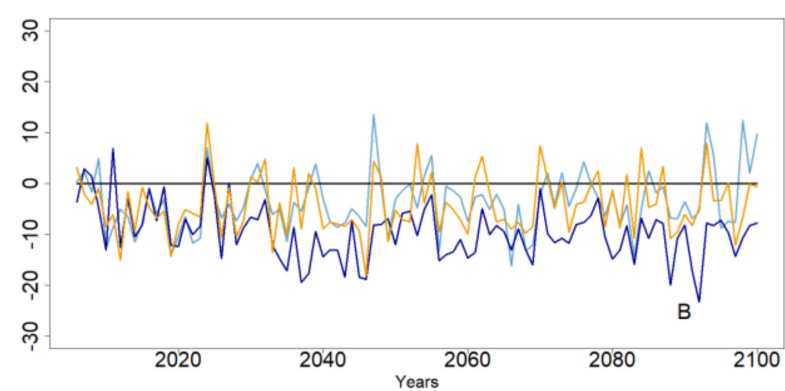

(B)

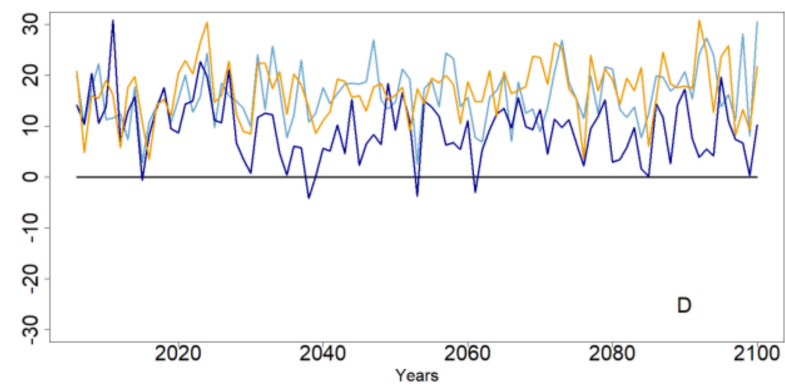

(D)

\section{$\mathrm{RCP} 2.6-\mathrm{RCP} 4.5-\mathrm{RCP} 8.5-\mathrm{RF}$}

Figure 5. Projected percentage change in wind speed compared to the observed reference period 2006-2020 in different regions of Lithuania based on the MPI—ESM—LR model: (A)—northern, (B)—southern, (C)—central, and (D)—coastal.

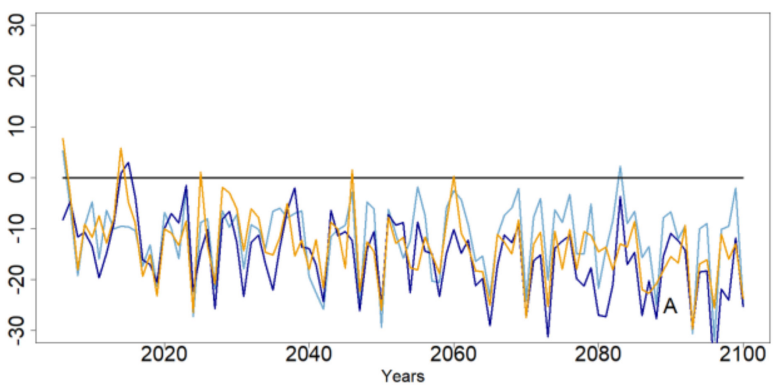

(A)

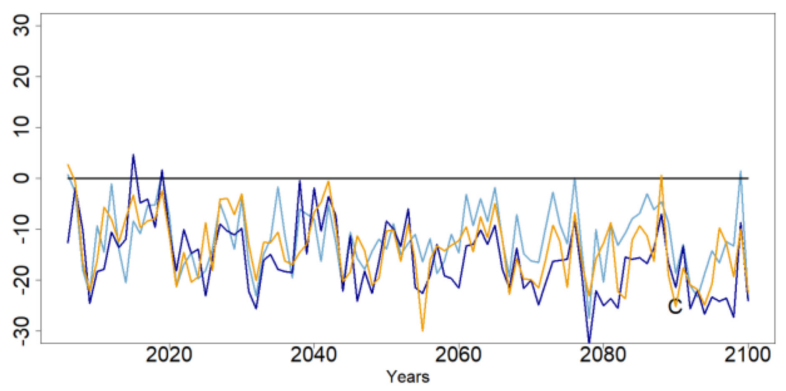

(C)

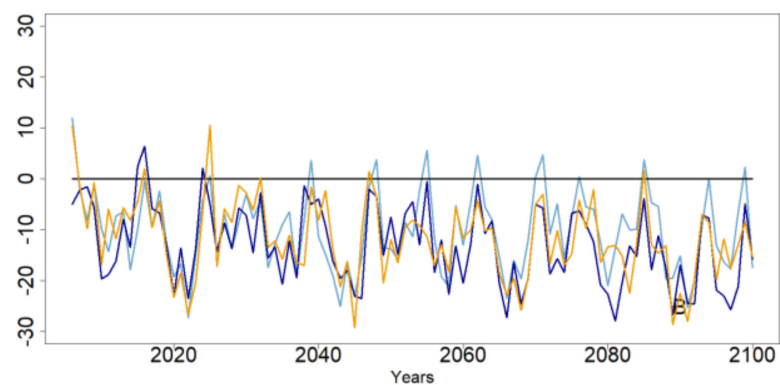

(B)

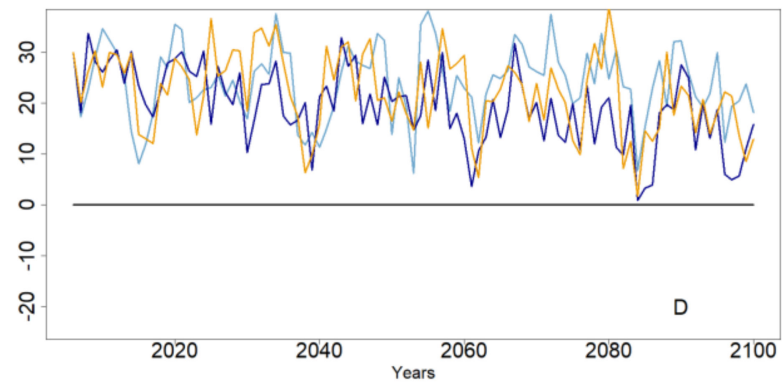

(D)

\section{- $\mathrm{RCP} 2.6-\mathrm{RCP} 4.5-\mathrm{RCP} 8.5-\mathrm{RF}$}

Figure 6. Projected percentage change in wind speed compared to the observed reference period 2006-2020 in different regions of Lithuania based on the HadGEM2—ES model: (A)—northern, (B)—southern, (C)—central, and (D)—coastal. 
The projected percentage change in wind speed compared to the observed reference period 2006-2020 in different regions of Lithuania based on the different GCM model is shown in Figures 4-6. In these graphs, the observed data for the period 2006-2020 were chosen as the reference period instead of the projected data. As a result, the graphs reflect the bias shift of projected results, which is different for each model.

It was found that the IPSL-CM5A-MR model analysis shows neither a significant increase nor decrease in any region except the coastal area (Figure 4). In this region, the wind speed tends to be higher than during the reference period. No change in wind speed in the coastal area is expected if climate change undergoes the RCP4.5 scenario. For the mildest RCP2.6 scenario, wind speed is going to increase insignificantly in the middle of the century and will be the same as over the reference period at the end of the century. According to the IPSL-CM5A-MR model, the RCP4.5 scenario tends to have the highest wind speed change values in every region analyzed.

The MPI-ESM-LR model outcomes (Figure 5) show similar tendencies to the ones of the IPSL-CM5A-MR model. Like the previous model, the analysis of wind data retrieved for this model shows a slight increase in wind speed under the RCP2.6 scenario in the far future in the northern, southern, and central regions. Again, the RCP4.5 scenario for this model will bring the highest decrease in wind speed in every part except the coastal area. The wind speed decrease may reach up to $5 \%(p<0.05)$ compared to wind speed during the reference period. The coastal region under any scenario may experience an increase in wind speed and energy production.

The HadGem2-ES model investigations provide the most homogeneous data (similar wind speed variations between every scenario) compared to the other models over every scenario analyzed (Figure 6). The projected change shows a very strong wind speed decrease in the northern region, especially at the end of the century. The decrease may reach up to $30 \%$, compared to the reference period. The southern and central regions may be affected by a reduction as well. The analysis of the data provided by the HadGem2-ES model provides exceptional fluctuation in wind speed change over the entire century in the southern region. In the southern part of Lithuania, all scenarios are very similar but have high annual fluctuations. Analysis of the wind data shows that the wind decrease in the central region is the highest under any scenario compared to other models.

The summary of wind speed changes according to the three analyzed models reveals the following regularities. The study of the mildest RCP2.6 scenario shows a minor decrease under the HadGEM2-ES model and the most substantial increase under IPSL-CM5A-MR and MPI-ESM-LR models, among other scenarios in every location. According to the analysis of the most severe scenario, RCP8.5, the weather conditions will not bring the most vital impact to wind speed change in this century. The results show a moderate shift towards lower wind speed. The analysis of wind data for the RCP4.5 scenario, which is the most likely to happen $[17,29]$, shows the strongest wind speed decrease in the northern, southern, and central Lithuanian regions under any model. The exception is the coastal region, where no significant wind speed change is expected in the IPSL-CM5A-MR model, but a slight increase is expected for the MPI-ESM-LR model and a considerable rise in wind speed is expected for the HadGEM2-ES model.

All other parts might have a slight (under IPSL-CM5A-MR and MPI-ESM-LR modelsup to $10 \%$ ) or significant decrease in wind speed (under HadGEM2-ES-up to 12\%).

\section{Discussion}

Wind speed investigations intensified in the late 20th century when the development of wind farms began in Europe. At that time, one of the most common summaries of wind observation data on the eastern coast of the Baltic Sea was presented in this study [30]. Observational data were and still are mostly used to calculate the energy produced by wind farms that are planned to be installed (e.g., WindPro [31]). The IPCC Assessment Report 4 (AR4), published in 2006, provided projections for various meteorological variables, including wind speeds up to 2100 in the 21st century [15]. The analysis of projected wind 
speed data mostly showed a greater or lesser increase in wind speed in the Baltic region, and especially in Northern Europe [9,32]. Meanwhile, the analysis of monitoring data revealed that, at least in the territory of Lithuania, the wind speed will decrease by about $0.3-0.6 \mathrm{~m} / \mathrm{s}$ in a decade [13,14].

Most of the analysis of the latest wind speed forecasts is based on data from the fifth IPCC report AR5 [15]. Trends in projected wind speeds vary: some authors suggest that wind speeds in Northern Europe, including the Baltic region, will increase slightly $[30,33-37]$, while others indicate that they will decrease $[18,29,36]$, and the third group of studies finds that wind speed will not change significantly [17,37]. For example, a statistically significant increase in wind energy over Northern Europe was found in [33] for the global world, with the $1.5^{\circ} \mathrm{C}$ increase in temperature, which is close to the ECP4.5 scenario. D. Carvalho et al. concluded in [9] that large-scale wind energetic resources will be lower, except in the Baltic Sea region, where the increase in wind energy is possible. This study found the reduction of the projected wind speed for the RCP4.5 scenario over Lithuanian territory in all models analyzed. The same tendency is shown in the latest study [18], where the decrease in monthly wind power density over the southern part of the Baltic Sea region is approximately $10 \%$ for the near, middle, and far future for the RCP4.5 scenario.

The analysis of the projected wind speed in the territory of Lithuania according to three models shows that the most unfavorable wind energy use scenario is the RCP4.5 scenario. The resulting reduction in wind speed is more than $12 \%$ and is one of the largest compared to data from other studies [10]. This finding supports other authors' opinions, who claim that the most realistic scenario might bring the highest wind speed decrease in Eastern Europe $[9,18,29,36]$. Because of this reason, wind power plants should be planned and designed with care. The pay-off period is going to be longer than expected while planning $[38,39]$. The current investigation shows that the best region for wind power plant building in Lithuania is the coastal area, where a wind speed increase was projected.

Changes in wind speed support the other authors' findings, who claim that RCP4.5 scenario will have the highest negative impact on wind speed change in Eastern Europe [9]. While the reduction in wind speed is the highest for the RCP4.5 scenario, the mildest RCP2.6 scenario is promising for wind energy production because wind speed will noticeably increase in the coastal area. The decrease rate in the central region is the highest under any scenario of wind speed and corresponds to the observed data obtained by the Lithuanian Hydrometeorological Service (LHMS) [14]. For example, projected wind speeds in the central part of the country will decrease slightly, while in the eastern part of the country, the decrease could be significant. The coastal region should have a strong positive impact on future energy production under any scenario. This region is the most promising for the development of the wind farm.

Comparison of findings in this study and historical wind speeds, provided by Lithuanian Hydrometeorological Services (LHMS), revealed that the HadGEM2-ES model for the RCP4.5 scenario projects the future wind speed changes the best [14].

\section{Conclusions}

This study analyzed the annual wind speed change in Lithuanian territory for the 21st century using the projected wind speed data to determine whether the decline in wind speed observed in recent decades on the territory of Lithuania will continue in the foreseeable future. The projected wind speed data of three global circulation models for the scenarios RCP2.6, RCP4.5, and RCP8.5 were analyzed individually, and the mean values were determined. A statistically significant decrease in wind speed was found for the RCP4.5 scenario under which wind speed might decrease up to $8 \%$ until the end of 21 st century. The results obtained indicate that for the mildest scenario, RCP2.6, wind speed will increase slightly, by up to $2 \%$ in the near and middle future, and by up to $3 \%$ in the far future. However, the coefficients on the trend variables were statistically insignificant. 
Under the RCP8.5 scenario, the decrease in wind speed of up to $4 \%$ was also found, but again was statistically insignificant.

The regional analysis of projected wind speed data revealed that there is no significant change in wind speed for the most optimistic climate scenario RCP2.6, nor for the most severe climate scenario, RCP8.5, on the territory of Lithuania, except in the coastal region. For these two scenarios, a statistically significant increase in wind speed in the coastal region was found. The RCP4.5 scenario provides the lowest wind speed values under all models over the entire country.

In summary, it can be concluded that the projected wind speeds in the territory of Lithuania have a clear downward trend for the RCP4.5 scenario. This finding corresponds to the decrease found in the observational data. However, the patterns in projected wind speeds are too small and statistically insignificant and, therefore, cannot change the course of green energy towards the wider use of wind energy for electricity generation.

Author Contributions: Conceptualization, J.J. and A.K.; methodology, J.J. and A.K.; software, J.J.; validation, J.J.; formal analysis, J.J.; investigation, J.J. and A.K.; resources, J.J. and A.K.; data curation, J.J. and A.K.; writing—original draft preparation, J.J. and A.K.; writing—review and editing, J.J. and A.K.; visualization, J.J.; supervision, A.K.; project administration, J.J. and A.K.; funding acquisition, J.J. and A.K. All authors have read and agreed to the published version of the manuscript.

Funding: This research received no external funding.

Institutional Review Board Statement: Not applicable.

Informed Consent Statement: Not applicable.

Data Availability Statement: Raw data is available at: https:/ / drive.google.com/drive/folders / 1YfTV8TAKwBI9Rqc9YcqOdP99qzRPs3qw?usp=sharing accessed on 27 August 2021.

Conflicts of Interest: The authors declare no conflict of interest.

\section{References}

1. Renewable Energy Directive I Energy. Available online: https://ec.europa.eu/energy/topics/renewable-energy/directivetargets-and-rules/renewable-energy-directive_en (accessed on 16 August 2021).

2. Directive (EU) 2018/2001 of the European Parliament and of the Council of 11 December 2018 on the Promotion of the Use of Energy from Renewable Sources (Recast) (Text with EEA Relevance). Available online: https:/ / eur-lex.europa.eu/legal-content/ EN/TXT/PDF/?uri=CELEX:32018L2001\&from=fr (accessed on 16 August 2021).

3. Home-Eurostat. Available online: https://ec.europa.eu/eurostat/ (accessed on 16 August 2021).

4. National Renewable Energy Action Plan. 2010. Available online: https://www.ena.lt/uploads/PDF-AEI/KITI-doc/EN/6anational-renewable-energy-action-plan-lithuania-en.pdf (accessed on 16 August 2021).

5. Tutak, M.; Brodny, J.; Siwiec, D.; Ulewicz, R.; Bindzár, P. Studying the Level of Sustainable Energy Development of the European Union Countries and Their Similarity Based on the Economic and Demographic Potential. Energies 2020, 13, 6643. [CrossRef]

6. Renewable Energy Statistics 2021. Available online: https://irena.org/publications/2021/Aug/Renewable-energy-statistics-2021 (accessed on 16 August 2021).

7. Rodikliu Duomenu Bazè-Oficialiosios Statistikos Portalas. Available online: https://osp.stat.gov.lt/statistiniu-rodikliu-analize\#/ (accessed on 16 August 2021).

8. Fan, Z.; Zhu, C. The optimization and the application for the wind turbine power-wind speed curve. Renew. Energy 2019, 140, 52-61. [CrossRef]

9. Santos, C.S.; Carvalho, D.; Rocha, A.; G, M. Potential impacts of climate change on European wind energy resource under the CMIP5 future climate projections. Renew. Energy 2020, 101, 29-40. [CrossRef]

10. Chen, L. Impacts of climate change on wind resources over North America based on NA-CORDEX. Renew. Energy 2020, 153, 1428-1438. [CrossRef]

11. Weber, J.; Gotzens, F.; Witthaut, D. Impact of strong climate change on the statistics of wind power Impact of strong climate change in on Europe the statistics of wind power generation Assessing the feasibility of using the heat temperature function for a long-term district heat demand fore. Energy Procedia 2018, 153, 22-28. [CrossRef]

12. Jung, C.; Schindler, D. Changing wind speed distributions under future global climate. Energy Convers. Manag. 2019, $198,111841$. [CrossRef]

13. International Conference of Young Scientists on Energy Issues, Kaunas, Lithuania, 29-30 May 2014. Available online: https:/ / cyseni.com/wp-content/archives/proceedings/Proceedings_of_CYSENI_2014.pdf (accessed on 16 August 2021). 
14. Vidutinès Klimatinių Rodikliu Reikšmės Lietuvoje Climate Averages for Lithuania. 1981. Available online: https://www.meteo.lt (accessed on 19 June 2021).

15. AR5 Climate Change 2013: The Physical Science Basis-IPCC. Available online: https://www.ipcc.ch/report/ar5/wg1/ (accessed on 16 August 2021).

16. Solaun, K.; Cerdá, E. Climate change impacts on renewable energy generation. A review of quantitative projections. Renew. Sustain. Energy Rev. 2019, 116, 109415. [CrossRef]

17. Tobin, I.; Jerez, S.; Vautard, R.; Thais, F.; Van Meijgaard, E.; Prein, A.; Déqué, M.; Kotlarski, S.; Maule, C.F.; Nikulin, G.; et al. Climate change impacts on the power generation potential of a European mid-century wind farms scenario. Environ. Res. Lett. 2016, 11, 034013. [CrossRef]

18. Martinez, A.; Iglesias, G. Wind resource evolution in Europe under different scenarios of climate change characterised by the novel Shared Socioeconomic Pathways. Energy Convers. Manag. 2021, 234, 113961. [CrossRef]

19. Global Surface Summary of the Day-GSOD-Datasets-NOAA Data Catalog. Available online: https://data.noaa.gov/dataset/ dataset/global-surface-summary-of-the-day-gsod (accessed on 16 August 2021).

20. PCMDI-CMIP5 Overview. Available online: https://pcmdi.llnl.gov/mips/cmip5/ (accessed on 16 August 2021).

21. Selpoint Function-RDocumentation. Available online: https://www.rdocumentation.org/packages/cmsaf/versions/1.9.0/ topics/selpoint (accessed on 16 August 2021).

22. Bedia, J.; Baño-Medina, J.; Legasa, M.N.; Iturbide, M.; Manzanas, R.; Herrera, S.; Casanueva, A.; San-Martín, D.; Cofiño, A.S.; Gutiérrez, J.M. Statistical downscaling with the downscaleR package (v3.1.0): Contribution to the VALUE intercomparison experiment. Geosci. Model Dev. 2020, 13, 1711-1735. [CrossRef]

23. Al Dhaheri, K.; Woon, W.L.; Aung, Z. Wind speed forecasting using statistical and machine learning methods: A case study in the UAE. In Data Analytics for Renewable Energy Integration: Informing the Generation and Distribution of Renewable Energy Lecture Notes in Computer Science; Springer International Publishing: Berlin/Heidelberg, Germany, 2017; pp. 107-120. [CrossRef]

24. Package "cmsaf". A Toolbox for CM SAF NetCDF Data. 2021. Available online: https://cran.r-project.org/web/packages/ cmsaf/cmsaf.pdf (accessed on 16 August 2021).

25. ncdf4: Interface to Unidata netCDF (Version 4 or Earlier) Format Data Files. 2019. Available online: https://cran.r-project.org/ web/packages/ncdf4/index.html (accessed on 16 August 2021).

26. Discover QGIS. Available online: https://www.qgis.org/en/site/about/index.html (accessed on 16 August 2021).

27. Blanco, I.; Diego, I.; Bueno, P.; Fernández, E.; Casas-Maldonado, F.; Esquinas, C.; Soriano, J.B.; Miravitlles, M. Geographical distribution of COPD prevalence in Europe, estimated by an inverse distance weighting interpolation technique. Int. J. Chron. Obstruct. Pulmon. Dis. 2018, 13, 57. [CrossRef]

28. Cofiño, A.S.; Bedia, J.; Iturbide, M.; Vega, M.; Herrera, S.; Fernández, J.; Frías, M.D.; Manzanas, R.; Gutiérrez, J.M. The ECOMS User Data Gateway: Towards seasonal forecast data provision and research reproducibility in the era of Climate Services. Clim. Serv. 2018, 9, 33-43. [CrossRef]

29. Davy, R.; Gnatiuk, N.; Pettersson, L.; Bobylev, L. Climate change impacts on wind energy potential in the European domain with a focus on the Black Sea. Renew. Sustain. Energy Rev. 2018, 81, 1652-1659. [CrossRef]

30. Devis, A.; Van Lipzig, N.P.M.; Demuzere, M. Should future wind speed changes be taken into account in wind farm development? Environ. Res. Lett. 2018, 13. [CrossRef]

31. windPRO । EMD International. Available online: https://www.emd.dk/windpro/ (accessed on 27 June 2021).

32. Gonzalez, P.L.M.; Brayshaw, D.J.; Zappa, G. The contribution of North Atlantic atmospheric circulation shifts to future wind speed projections for wind power over Europe. Clim. Dyn. 2019, 53, 4095-4113. [CrossRef]

33. Hosking, J.S.; Macleod, D.; Phillips, T.; Holmes, C.R.; Watson, P.; Shuckburgh, E.F.; Mitchell, D. Changes in European wind energy generation potential within a $1.5^{\circ} \mathrm{C}$ warmer world. Environ. Res. Lett. 2018, 13, 054032. [CrossRef]

34. Gaetani, M.; Monforti, F.; Huld, T.; Dosio, A. Climate Modelling and Renewable Energy Resource Assessment Resilience of Large Investments and Critical Infrastructures in Europe to Climate Change (CCMFF) View Project Saharan Heat Low and West African Climate View Project. 2015. Available online: https://www.researchgate.net/publication/275342727 (accessed on 16 August 2021).

35. Hueging, H.; Haas, R.; Born, K.; Jacob, D.; Pinto, J.G. Regional changes in wind energy potential over Europe using regional climate model ensemble projections. J. Appl. Meteorol. Climatol. 2013, 52, 903-917. [CrossRef]

36. Barstad, I.; Sorteberg, A.; Mesquita, M.d.S. Present and future offshore wind power potential in northern Europe based on downscaled global climate runs with adjusted SST and sea ice cover. Renew. Energy 2012, 44, 398-405. [CrossRef]

37. Tobin, I.; Vautard, R.; Balog, I.; Bréon, F.M.; Jerez, S.; Ruti, P.M.; Thais, F.; Vrac, M.; Yiou, P. Assessing climate change impacts on European wind energy from ENSEMBLES high-resolution climate projections. Clim. Change 2015, 128, 99-112. [CrossRef]

38. Solaun, K.; Cerdá, E. Impacts of climate change on wind energy power-Four wind farms in Spain. Renew. Energy 2020, 145, 1306-1316. [CrossRef]

39. Akhtar, N.; Geyer, B.; Rockel, B.; Sommer, P.S.; Schrum, C. Accelerating deployment of offshore wind energy alter wind climate and reduce future power generation potentials. Sci. Rep. 2021, 11, 11826. [CrossRef] 